\title{
ANALISIS PENGENDALIAN KUALITAS MENGGUNAKAN METODE TAGUCHI PADA UMKM RUBBER SEAL RM PRODUCTS GENUINE PARTS SUKUN, MALANG
}

\author{
Putri Riski Maulidia ${ }^{1}$, Nelly Budiharti ${ }^{2}$, Emmalia Adriantantri $^{3}$ \\ ${ }^{1}$ Prodi Teknik Industri S-1, Fakultas Teknologi Industri, Institut Teknologi Nasional Malang \\ Email: putri.maulidinna@gmail.com
}

\begin{abstract}
Abstrak, RM Products Genuine Parts merupakan UMKM yang memproduksi rubber seal. Produk O-Ringnya memiliki jumlah rata-rata produk cacat $26 \%$ yang melebihi standar perusahaan yaitu 5\% yang disebabkan oleh faktor bahan baku dan proses produksi. RM Products Genuine Parts menerapkan metode Taguchi yang dilakukan melalui eksperimen, uji ANOVA dan uji $F$ untuk mengetahui faktor yang berpengaruh terhadap kecacatan. Tujuan penelitian ini adalah usulan perbaikan berupa kombinasi faktor dan level faktor optimal sebagai upaya mengurangi produk cacat. Berdasarkan hasil penelitian, diperoleh kombinasi faktor dan level faktor optimal yaitu faktor A (tebal karet) level $3(1,5 \mathrm{~cm})$, faktor B (berat karet) level 2 (5 gram), faktor C (suhu mesih) level $1\left(135^{\circ} \mathrm{C}\right)$ dan faktor D (waktu pressing) level 2 (6 menit). Nilai variabilitas menurun dari 30,28 menjadi 17,8998 dan persentase produk cacat menurun dari $26,1 \%$ menjadi $11,75 \%$ yang masih melebihi standar maksimum cacat yang diinginkan perusahaan, karena hanya menganalisis faktor bahan baku dan mesin press manual.
\end{abstract}

Kata Kunci : Rubber Seal, Eksperimen, Taguchi, standar cacat produk

\section{PENDAHULUAN}

Indonesia merupakan salah satu produsen dan eksportir karet terbesar di dunia (Sumber: Kementrian Pertanian, 2019). Penggunaan karet di dunia secara umum antara lain $65 \%$ untuk kendaraan bermotor, 20\% barang teknik industri, $10 \%$ barang keperluan umum dan 5\% barang jadi lateks. Barang yang dapat dibuat dari karet alam antara lain isolator alat masak, bahan pembuatan alas kaki, aksesoris olah raga, pelengkap kendaraan bermotor dan lain-lain. Pada kendaraan bermotor, karet digunakan sebagai ban, komponen peredam getaran seperti engine mounting maupun sebagai komponen penutup tangki seperti rubber seal (Sumber: Rubber Association of. Indonesia, 2019).

RM Products Genuine Parts, merupakan salah satu jenis usaha mikro kecil menengah (UMKM) yang didirikan pada tahun 1994 oleh Pak Candra. Usaha ini bergerak dalam produksi rubber seal berbagai tipe dan ukuran sebagai pelengkap kendaraan bermotor. Produk ini diproduksi secara berkelanjutan menggunakan mesin press manual dengan pengerjaan tangan. Distribusi produk ini telah sampai ke berbagai retailer di Jawa Timur, Jawa Tengah, Jawa Barat dan Kalimantan.

Namun, pada saat inspeksi masih ditemukan beberapa produk cacat. Tabel 1 menyajikan data perbandingan jumlah produksi dengan jumlah produk cacat periode Agustus November 2019 sebagai berikut:

Tabel 1 Data Perbandingan Jumlah Produksi dan Jumlah Produk Cacat O-Ring RM Products Genuine Parts Periode Agustus- November 2019

\begin{tabular}{|c|c|c|c|}
\hline Bulan & $\begin{array}{c}\text { Produks } \\
\text { i (Unit) }\end{array}$ & $\begin{array}{c}\text { Produ } \\
\mathbf{k} \\
\text { Cacat } \\
\text { (Unit) }\end{array}$ & $\begin{array}{c}\text { Persentas } \\
\text { e Produk } \\
\text { Cacat } \\
\text { (\%) }\end{array}$ \\
\hline Agustus & 1400 & 382 & 27,3 \\
\hline $\begin{array}{c}\text { Septembe } \\
\text { r }\end{array}$ & 1600 & 396 & 24,8 \\
\hline Oktober & 1200 & 328 & 27,3 \\
\hline $\begin{array}{c}\text { Novembe } \\
\text { r }\end{array}$ & 1500 & 376 & 25,1 \\
\hline Total & $\mathbf{5 7 0 0}$ & $\mathbf{1 4 2 8}$ & $\mathbf{1 0 4 , 4}$ \\
\hline $\begin{array}{c}\text { Rata- } \\
\text { Rata }\end{array}$ & $\mathbf{1 4 2 5}$ & $\mathbf{3 5 7}$ & $\mathbf{2 6 , 1}$ \\
\hline
\end{tabular}

Sumber: UMKM RM Products Genuine Parts

Berdasarkan tabel 1 dapat diketahui bahwa jumlah rubber seal tipe O-Ring yang cacat mencapai rata - rata sebesar $26 \%$ dari jumlah total produksi secara keseluruhan. Jumlah tersebut melebihi batas standar kecacatan yang ditetapkan oleh perusahaan yaitu sebesar 5\%. Hal ini dapat disebabkan oleh 
berbagai faktor seperti proses produksi yang bersifat manual, faktor komposisi bahan ataupun faktor perusahaan yang belum mengetahui kombinasi faktor kontrol dan level faktor optimal. Perlu dilakukan penelitian untuk mengatasi permasalahan kualitas rubber seal terhadap faktor penyebab cacat menggunakan teknik pengendalian kualitas yaitu metode Taguchi.

Metode Taguchi diperkenalkan oleh pakar manajemen kualitas dari jepang, Genichi Taguchi pada tahun 1940 (Muharom dan Siswadi, 2015). Metode ini merupakan metode pendekatan Design of Eksperiment yang merupakan elemen kunci untuk mencapai kualitas tinggi dengan biaya yang minimum (Nekere, 2012). Design of Experiment adalah suatu kegiatan yang dilakukan dengan memberikan perlakuan atau treatment pada suatu objek yang digunakan untuk mencari pengaruh perlakuan terhadap faktor lain dalam kondisi yang dikendalikan (Sugiyono, 2012).

Pada umumnya metode ini bertujuan untuk memperbaiki kualitas produk dan proses produksi. Menurut Bagchi (2013), tujuan metode Taguchi adalah untuk membantu meningkatkan kemampuan proses dan mengurangi penyebab variabilitas produksi. Metode ini mengkombinasikan hasil eksperimen melalui faktor dan level faktor optimal yang dalam waktu bersamaan menghemat waktu dan biaya (Muharom dan Siswadi, 2015). Hasil metode ini adalah kombinasi faktor dan levelnya yang kokoh (robust) terhadap faktor pengganggu (noise).

Penggunaan metode Taguchi pada penelitian ini diharapkan mampu memperbaiki kualitas rubber seal tipe O-Ring sebagai upaya mengurangi persentase produk cacat yang cukup tinggi di UMKM Rubber Seal RM Products Genuine Parts. Dengan menggunakan metode ini diharapkan dapat diketahui faktor dan level optimalnya untuk meningkatkan kualitas rubber seal tipe O-Ring.

\section{METODE}

Penelitian ini berjenis penelitian eksperimen karena dilakukan dengan memberikan perlakuan atau treatment pada obyek penelitian yaitu rubber seal tipe O-Ring dalam kondisi yang terkendalikan. Perlakuan yang diberikan pada rubber seal tipe O-Ring dilakukan dengan setting kondisi mesin dan bahan baku pada proses produksi sesuai dengan level faktor pada susunan percobaan. Teknik pengumpulan data dilakukan dengan studi lapangan/observasi, wawancara, dokumentasi dan brainstorming dengan karyawan di lokasi penelitian.

Metode yang digunakan pada penelitian ini adalah metode Taguchi / metode dengan pendekatan Design of Eksperiment yang merupakan elemen kunci untuk mencapai kualitas tinggi dengan biaya yang minimum (Nekere, 2012). Design of Experiment adalah suatu kegiatan yang dilakukan dengan memberikan perlakuan atau treatment pada suatu objek yang digunakan untuk mencari pengaruh perlakuan terhadap faktor lain dalam kondisi yang dikendalikan (Sugiyono, 2012). Metode ini bertujuan untuk memperbaiki kualitas produk dan proses produksi. Menurut Bagchi (2013), tujuan metode Taguchi adalah untuk membantu meningkatkan kemampuan proses dan mengurangi penyebab variabilitas produksi. Metode ini mengkombinasikan hasil eksperimen melalui faktor dan level faktor optimal serta dalam waktu bersamaan mengurangi jumlah percobaan sehingga menghemat waktu dan biaya (Muharom dan Siswadi, 2015). Hasil metode ini adalah kombinasi faktor dan levelnya yang kokoh (robust) terhadap faktor pengganggu (noise) (Liu, dkk, 2019). Eksperimen Taguchi dilakukan dengan langkah-langkah sebagai berikut:

1. Merumuskan Permasalahan

2. Menentukan Tujuan Eksperimen

3. Menentukan Faktor yang Mempengaruhi Kondisi Obyek Penelitian

4. Memisahkan Faktor Kontrol dan Faktor Noise

Faktor kontrol adalah faktor yang dapat dikendalikan oleh peneliti. Sedangkan faktor noise adalah faktor yang nilainya tidak dapat dikendalikan. Penentuan faktor dapat dilakukan melalui brainstorming.

5. Menentukan Karakteristik Kualitas yang sesuai

Karakteristik kualitas adalah obyek yang menarik dari suatu produk atau proses. Karakteristik kualitas yang digunakan harus ditentukan dari awal perancangan eksperimen. Karakteristik kualitas dibagi menjadi 3 yaitu: 
a) Nominal is The Best

Karakteristik kualitas yang menuju nilai target pada suatu nilai tertentu. Contoh: ketebalan, berat dan tekanan.

b) Smaller is The Best

Pencapaian karakteristik apabila semakin kecil / mendekati nol adalah semakin baik. Contoh: produk gagal (cacat), pemborosan, kebisingan dan limbah.

c) Larger is The Best

Pencapaian karakteristik kualitas semakin besar semakin baik. Contoh: kekuatan dan ketahanan.

6. Menentukan Jumlah Level dan Level Faktor

7. Menghitung Derajat Kebebasan

Derajat kebebasan menunjukkan jumlah minimum eksperimen.

8. Pemilihan Orthogonal Array

Pemilihan orthogonal array bergantung pada jumlah faktor dan level faktor dengan rumus: $\mathrm{La}\left(\mathrm{b}^{\mathrm{c}}\right)$
Dimana:

L : Tabel Orthogonal Array

a : Jumlah Eksperimen

b : Jumlah Level

c : Jumlah Faktor

9. Pengisian Kolom Faktor dan Interaksi ke dalam Matriks Orthogonal

10. Pelaksanaan Eksperimen

11. Analisis Hasil Eksperimen

Analisis hasil eksperimen dilakukan dengan langkah-langkah berikut:

a. Analisis Variansi Taguchi

Analisis ini dilakukan dengan menggunakan uji ANOVA sebagai berikut:

1) Membuat tabel data variabel

2) Menghitung rata - rata untuk masing masing eksperimen

3) Membuat tabel Anova dua arah sebagai berikut:

Tabel 2 Respon Pengaruh Faktor

\begin{tabular}{|c|c|c|c|c|c|c|c|}
\hline $\begin{array}{c}\text { Sumber } \\
\text { Variansi }\end{array}$ & SS & DOF & MS & F-Ratio & SS' & Rho $\%$ & F-tabel \\
\hline Faktor A & SSA & DOFA & MSA & FA & MSA/MSE & SS'A/SST & $\begin{array}{c}\text { F } \alpha \text { (DOF A; } \\
\text { DOFTotal) }\end{array}$ \\
\hline Faktor B & SSB & DOFB & MSB & FB & MSB/MSE & SS'B/SST & $\begin{array}{c}\text { F } \alpha \text { (DOF B; } \\
\text { DOFTotal) }\end{array}$ \\
\hline Faktor X & SSX & DOFX & MSX & FX & $\begin{array}{c}\text { MSX } \\
\text { /MSE }\end{array}$ & SS'X/SST & $\begin{array}{c}\text { F } \alpha \text { (DOF X; } \\
\text { DOFTotal) }\end{array}$ \\
\hline Error & SSE & DOFE & MSE & - & SS'E & SS'E/SST & - \\
\hline Total & SST & DOFT & - & - & SST & $100 \%$ & - \\
\hline
\end{tabular}

Sumber: Ermawati \& Hartati (2014)

Berdasarkan tabel 2 tersebut dilakukan perhitungan sebagai berikut:

- Menghitung Rata-Rata Eksperimen

$$
y=\sum \bar{y}
$$

- Menghitung Derajat Bebas (DOF)

DOF faktor $\mathrm{X}=$ (jumlah level faktor $\mathrm{X}-1$ )

$\mathrm{DOF}_{\text {Total }}=\mathrm{DOF}_{\mathrm{A}}+\mathrm{DOF}_{\mathrm{B}}+\ldots+\mathrm{DOF}_{\mathrm{X}}$

$$
\mathrm{DOF}_{\mathrm{E}}=\mathrm{DOF}_{\mathrm{T}}-\Sigma \mathrm{DOF}_{\mathrm{X}}
$$

- Menghitung Rata-Rata Level Faktor $\left(\overline{\mathrm{X}}_{1}\right)$

$$
\overline{\mathrm{X} 1}=\frac{\overline{\mathrm{y}} \text { respon level X1}}{\sum \text { level }}
$$

- Menghitung Kuadrat Faktor (Sum of Square)

$$
\begin{gathered}
\mathrm{SS}_{\mathrm{X}}=\frac{\sum \mathrm{X} 1^{2}}{\mathrm{n}_{\mathrm{X} 1}}+\frac{\sum \mathrm{X} 2^{2}}{\mathrm{n}_{\mathrm{X} 2}}+\frac{\sum \mathrm{X} 3^{2}}{\mathrm{n}_{\mathrm{X} 3}} \\
-\frac{\sum \overline{\mathrm{y}}^{2}}{\mathrm{n}}
\end{gathered}
$$

- Menghitung Kuadrat Total $\left(\mathrm{SS}_{\mathrm{T}}\right)$

$$
\mathrm{SS}_{\mathrm{T}}=\sum(\bar{y})^{2}
$$

- Menghitung Rata-Rata Kuadrat $\left(\mathrm{SS}_{\mathrm{M}}\right)$

$$
\mathrm{SS}_{\mathrm{M}}=\mathrm{n} \cdot \overline{\mathrm{y}}^{2}
$$

- Menghitung Kuadrat Faktor $\left(\mathrm{SS}_{\mathrm{F}}\right)$

$$
\mathrm{SS}_{\mathrm{F}}=\Sigma \mathrm{SS}_{\mathrm{X}}
$$


- Menghitung Kuadrat Error $\left(\mathrm{SS}_{\mathrm{E}}\right)$

$$
\mathrm{SS}_{\mathrm{E}}=\mathrm{SS}_{\mathrm{T}}-\mathrm{SS}_{\mathrm{M}}-\mathrm{SS}_{\text {Faktor }}
$$

- Menghitung Rata-Rata Kuadrat Faktor $\left(\mathrm{MS}_{\mathrm{X}}\right)$

$$
\mathrm{MS}_{\mathrm{X}}=\frac{\mathrm{SS}_{\mathrm{X}}}{\mathrm{DOF}_{\mathrm{X}}}
$$

- Menghitung Rata-Rata Kuadrat Error $\left(\mathrm{MS}_{\mathrm{E}}\right)$

$$
\mathrm{MS}_{\mathrm{E}}=\frac{\mathrm{SS}_{\mathrm{E}}}{\mathrm{DOF}_{\mathrm{E}}}
$$

- Menghitung Nilai F-Ratio Faktor $\left(\mathrm{F}_{\mathrm{X}}\right)$

$$
\mathrm{F}_{\mathrm{X}}=\frac{\mathrm{MS}_{\mathrm{X}}}{\mathrm{MS}_{\mathrm{E}}}
$$

- Menghitung Pure Sum of Square Faktor $\left(\mathrm{SS}^{\prime} \mathrm{x}\right)$

$$
\mathrm{SS}_{\mathrm{X}}{ }_{\mathrm{X}}=\mathrm{SS}_{\mathrm{X}}-\left(\mathrm{DOF}_{\mathrm{X}} \times \mathrm{MS}_{\mathrm{E}}\right)
$$

- Menghitung Persentase Kontribusi MasingMasing Faktor (Rho\%)

$$
\text { Rho }{ }_{\mathrm{X}}=\frac{\mathrm{SS}_{\mathrm{X}}^{\prime}}{\mathrm{SS}_{\mathrm{T}}} \times 100 \%
$$

b. Melakukan Pengujian F

Uji $F$ dilakukan dengan membandingkan variansi tiap faktor dan variansi error. Hipotesis yang digunakan sebagai berikut:

Ho: Tidak ada pengaruh perlakuan

$\mathrm{H}_{1}$ : Ada pengaruh perlakuan

c. Signal to Noise Ratio (Rasio S/N)

Rasio S/N digunakan untuk memfokuskan pemilihan faktor yang memiliki kontribusi terhadap pengurangan variasi suatu respon. Nilai Rasio S/N yang digunakan bergantung pada jenis karakteristik yang digunakan dalam penelitian. Karakteristik Nilai S/N Ratio untuk tiap karakteristik adalah sebagai berikut:

1) Nominal The Better

$$
\begin{gathered}
S / N^{T}=10 \log \frac{\bar{y}^{2}}{S^{2}} \\
\text { Dengan } \bar{y}^{2}=\frac{1}{n} \sum_{i=1}^{n} y_{1}{ }^{2} \\
S^{2}=\frac{1}{n-1} \sum_{i=1}^{n}\left(y_{1}-\bar{y}\right)^{2}
\end{gathered}
$$

2) Smaller The Better

$$
\mathrm{S} / \mathrm{N}_{1}=-10 \log \left(\frac{1}{\mathrm{n}} \sum_{\mathrm{i}=1}^{\mathrm{n}} \mathrm{y}_{1}{ }^{2}\right)
$$

3) Larger The Better

$$
S / N_{1}=-10 \log \left(\frac{1}{n} \sum_{i=1}^{n} y_{1}^{2}\right)
$$

Namun, dalam konsep Signal to Noise Ratio (Rasio S/N) menurut Belavendram (1995) dalam Destantri Anggun (2018), apapun karakteristik kualitas yang dipilih dalam suatu eksperimen, perhitungan nilai Rasio S/N (variabilitas) selalu diinterpretasikan dengan karakteristik larger the better yaitu semakin besar nilainya maka semakin baik.

d. Stategi Pooling Up

Strategi ini dilakukan bila faktor yang diamati tidak signifikan secara statistik sehingga perlu dilakukan pooling up dengan rumus sebagai berikut:

1) Perhitungan Sum of Square Pooled

$$
\mathrm{SS}_{\text {Pooled }}=\mathrm{SS}_{\mathrm{E}}+\mathrm{SS}_{\mathrm{X}}
$$

2) Perhitungan Derajat Kebebasan Pooled

$$
\mathrm{DOF}_{\text {Pooled }}=\mathrm{DOF}_{\mathrm{E}}+\mathrm{DF}_{\mathrm{C}}
$$

3) Perhitungan Mean Square Pooled

$$
\mathrm{MS}_{\text {Pooled }}=\frac{\mathrm{SS}_{\text {Pooled }}}{\mathrm{DOF}_{\text {Pooled }}}
$$

4) Perhitungan Pure Sum of Square Pooled (SS' ${ }_{\text {Pooled }}$

$$
\mathrm{SS}^{\prime}{ }_{\mathrm{X} \text { Pooled }}=\mathrm{SS}_{\mathrm{X}}+\left(\mathrm{DOF}_{\mathrm{X}} \cdot \mathrm{MS}_{\text {Pooled }}\right)
$$

12. Interpretasi Hasil Eksperimen Hal-hal yang perlu diperhatikan dalam interpretasi hasil eksperimen Taguchi:

a. Persen Kontribusi, yaitu besarnya persentase signifikansi faktor dan interaksi faktor terhadap total variansi objek yang diamati.

b. Interval Kepercayaan, yaitu interval yang terdiri dari nilai maksimum dan minimum yang mencakup rata-rata.

13. Eksperimen Konfirmasi

Eksperimen konfirmasi sebagai langkah validasi berhasil apabila:

a. Terjadi perbaikan setelah eksperimen Taguchi dilaksanakan.

b. Hasil eksperimen konfirmasi mendekati nilai yang diprediksi. 


\section{HASIL DAN PEMBAHASAN \\ Pengumpulan Data}

Data yang dikumpulkan pada penelitian ini adalah data urutan proses produksi dan data faktor penyebab produk cacat yaitu produk yang sobek, terlalu tipis, terpotong (tidak utuh) dan memiliki bentuk cetakan karet yang tidak rapi yang didapat melalui observasi, wawancara dan brainstorming dengan pekerja di lokasi penelitian. Faktor dan level faktor yang memberikan pengaruh terhadap kualitas rubber seal tipe O-Ring perlu diidentifikasi dan dianalisis sebagai kombinasi yang mempengaruhi hasil eksperimen.

Berdasarkan brainstorming, wawancara, observasi dan pencatatan langsung di lokasi penelitian, diperoleh faktor dan level faktor yang dianggap memiliki kontribusi dalam menyebabkan kecacatan produk dan akan digunakan pada eksperimen sebagaimana disajikan pada tabel berikut:

Tabel 3 Kombinasi Faktor dan Level Faktor

\begin{tabular}{|c|l|c|c|c|}
\hline \multirow{2}{*}{ Kode } & \multirow{2}{*}{$\begin{array}{c}\text { Faktor } \\
\text { Kontrol }\end{array}$} & \multicolumn{3}{|c|}{ Level Faktor } \\
\cline { 3 - 5 } $\mathrm{A}$ & $\begin{array}{l}\text { Tebal karet } \\
\text { padatan }\end{array}$ & $0,5 \mathrm{~cm}$ & $1 \mathrm{~cm}$ & $1,5 \mathrm{~cm}$ \\
\hline $\mathrm{B}$ & $\begin{array}{l}\text { Berat karet } \\
\text { padatan }\end{array}$ & 2 gram & $5 \mathrm{gram}$ & $8 \mathrm{gram}$ \\
\hline $\mathrm{C}$ & $\begin{array}{l}\text { Suhu mesin } \\
\text { press }\end{array}$ & $135^{\circ} \mathrm{C}$ & $180^{\circ} \mathrm{C}$ & $210^{\circ} \mathrm{C}$ \\
\hline $\mathrm{D}$ & $\begin{array}{l}\text { Waktu } \\
\text { pressing }\end{array}$ & 2 menit & 6 menit & $\begin{array}{c}10 \\
\text { menit }\end{array}$ \\
\hline
\end{tabular}

Sumber: UMKM Rubber Seal RM Products Genuine Parts

Faktor dan level faktor pada tabel 3 tersebut akan dikombinasikan sebagai susunan percobaan yang disesuaikan dengan orthogonal array yang dipilih pada tahap selanjutnya.

\section{Pemilihan Orthoginal Array}

Jenis tabel orthogonal yang digunakan adalah kondisi 3 three level factors karena setiap faktor terdiri dari 3 level faktor sehingga sehingga diperoleh tabel orthogonal array sebagai berikut:
Tabel 4 Orthogonal Array $\mathrm{L}_{9}(3)^{4}$

\begin{tabular}{|c|c|c|c|c|}
\cline { 1 - 4 } Ekperimen ke- & A & B & C & D \\
\hline 1 & 1 & 1 & 1 & 1 \\
\hline 2 & 1 & 2 & 2 & 2 \\
\hline 3 & 1 & 3 & 3 & 3 \\
\hline 4 & 2 & 1 & 2 & 3 \\
\hline 5 & 2 & 2 & 3 & 1 \\
\hline 6 & 2 & 3 & 1 & 0 \\
\hline 7 & 3 & 1 & 3 & 2 \\
\hline 8 & 3 & 2 & 1 & 3 \\
\hline 9 & 3 & 3 & 2 & 1 \\
\hline
\end{tabular}

Sumber: International Surface Engineering Congress and Exposition, 2003

Orthogonal array pada tabel 4 tersebut digunakan dalam menentukan susunan percobaan yang disesuaikan pada faktor dan level faktor yang telah diperoleh sebelumnya.

\section{Penentuan Jumlah Eksperimen dan Replikasi}

Penelitian ini menggunakan 4 faktor yang masing-masing terdiri dari 3 level faktor dengan jumlah eksperimen 9 kali dan 3 kali replikasi dengan total keseluruhan data pengamatan adalah 27 data. Berikut tabel susunan percobaan tiap perlakuan:

Tabel 5 Susunan Percobaan Tiap Perlakuan

\begin{tabular}{|c|c|c|c|c|}
\hline $\begin{array}{r}\text { Level } \\
\text { Faktor }\end{array}$ & $\begin{array}{c}\text { Tebal } \\
\text { karet } \\
\text { padata } \\
\mathrm{n}(\mathrm{A})\end{array}$ & $\begin{array}{c}\text { Berat } \\
\text { karet } \\
\text { padata } \\
\mathrm{n}(\mathrm{B})\end{array}$ & $\begin{array}{c}\text { Suhu } \\
\text { Mesin } \\
\text { men ke - } \\
\text { Press } \\
\text { (C) }\end{array}$ & $\begin{array}{c}\text { Waktu } \\
\text { Pressing } \\
\text { (D) }\end{array}$ \\
\hline 1 & $0,5 \mathrm{~cm}$ & $2 \mathrm{gram}$ & $135^{\circ} \mathrm{C}$ & 2 menit \\
\hline 2 & $0,5 \mathrm{~cm}$ & $5 \mathrm{gram}$ & $180^{\circ} \mathrm{C}$ & 6 menit \\
\hline 3 & $0,5 \mathrm{~cm}$ & $8 \mathrm{gram}$ & $210^{\circ} \mathrm{C}$ & 10 menit \\
\hline 4 & $1 \mathrm{~cm}$ & $2 \mathrm{gram}$ & $180^{\circ} \mathrm{C}$ & 10 menit \\
\hline 5 & $1 \mathrm{~cm}$ & $5 \mathrm{gram}$ & $210^{\circ} \mathrm{C}$ & 2 menit \\
\hline 6 & $1 \mathrm{~cm}$ & $8 \mathrm{gram}$ & $135^{\circ} \mathrm{C}$ & 6 menit \\
\hline 7 & $1,5 \mathrm{~cm}$ & $2 \mathrm{gram}$ & $210^{\circ} \mathrm{C}$ & 6 menit \\
\hline 8 & $1,5 \mathrm{~cm}$ & $5 \mathrm{gram}$ & $135^{\circ} \mathrm{C}$ & 10 menit \\
\hline 9 & $1,5 \mathrm{~cm}$ & 8 gram & $180^{\circ} \mathrm{C}$ & 2 menit \\
\hline
\end{tabular}

Sumber: Pengolahan Data

Tabel 5 tersebut akan menjadi dasar dalam melakukan memproduksi O-Ring yang mana dilakukan menggunakan kombinasi tertentu pada masing-masing eksperimen yang telah disesuaikan dengan orthogonal array terpilih. 


\section{Pengumpulan Data Hasil Eksperimen}

Setelah pelaksanaan eksperimen sesuai tabel susunan percobaan tiap perlakuan, data nilai hasil uji eksperimen Taguchi berupa jumlah produk cacat yaitu produk yang sobek, terlalu tipis, terpotong (tidak utuh) dan memiliki bentuk cetakan yang tidak rapi dihitung proporsinya dengan cara dibagi 80 unit produk yang diinspeksi dalam 1 hari sebagai berikut:

Tabel 6 Data Proporsi Cacat Hasil Uji Eksperimen Taguchi (satuan Unit)

\begin{tabular}{|c|c|c|c|c|c|c|c|c|}
\hline $\begin{array}{c}\text { Eksp } \\
\text { ke- } \\
\text { (y) }\end{array}$ & A & B & C & D & Rep 1 & Rep 2 & Rep 3 & $\begin{array}{c}\text { Rata- } \\
\text { rata } \\
(\bar{y})\end{array}$ \\
\hline 1 & 1 & 1 & 1 & 1 & 0,3000 & 0,2500 & 0,2000 & 0,2500 \\
\hline 2 & 1 & 2 & 2 & 2 & 0,1625 & 0,0625 & 0,0250 & 0,0833 \\
\hline 3 & 1 & 3 & 3 & 3 & 0,1375 & 0,1875 & 0,1000 & 0,1417 \\
\hline 4 & 2 & 1 & 2 & 3 & 0,1250 & 0,1125 & 0,0375 & 0,0917 \\
\hline 5 & 2 & 2 & 3 & 1 & 0,1875 & 0,1375 & 0,1125 & 0,1458 \\
\hline 6 & 2 & 3 & 1 & 2 & 0,0875 & 0,0375 & 0,0125 & 0,0458 \\
\hline 7 & 3 & 1 & 3 & 2 & 0,2000 & 0,1375 & 0,0375 & 0,1250 \\
\hline 8 & 3 & 2 & 1 & 3 & 0,0500 & 0,0125 & 0,0125 & 0,0250 \\
\hline 9 & 3 & 3 & 2 & 1 & 0,1000 & 0,0750 & 0,0250 & 0,0667 \\
\hline \multicolumn{8}{|c|}{ Jumlah } \\
\hline \multicolumn{8}{|c|}{ Rata-rata } & \\
\hline
\end{tabular}

Sumber: Pengolahan Data

Data proporsi cacat pada tabel 6 tersebut akan digunakan untuk menghitung nilai rata-rata dan nilai Rasio $\mathrm{S} / \mathrm{N}$ (variabilitas) melalui perhitungan nilai respon faktor dan level faktor, uji ANOVA dan Uji F dan strategi pooling up pada tahap selanjutnya.
Perhitungan Respon Rata-Rata Level Faktor Hasil uji dan replikasi eksperimen dihitung respon nilai rata-rata setiap faktor dan level faktornya sehingga dituliskan hasil sebagai berikut:

Tabel 7 Hasil Respon Nilai Rata-Rata Tiap Faktor dan Level Faktor

\begin{tabular}{|c|c|c|c|c|}
\hline & A & B & C & D \\
\hline Level 1 & 0,1583 & 0,1556 & 0,1069 & 0,1542 \\
\hline Level 2 & 0,0944 & 0,0847 & 0,0806 & 0,0847 \\
\hline Level 3 & 0,0722 & 0,0847 & 0,1375 & 0,0861 \\
\hline $\begin{array}{c}\text { Selisih } \\
\text { (max-min) }\end{array}$ & 0,0861 & 0,0708 & 0,0569 & 0,0694 \\
\hline Optimum & A3 & B2 & C2 & D2 \\
\hline
\end{tabular}

Sumber: Pengolahan Data

Berdasarkan tabel 7, didapatkan respon nilai rata-rata kualitas rubber seal tipe O-Ring pada kondisi optimal yang sesuai dengan karakteristitik kualitas smaller the better yaitu faktor A (tebal irisan karet padatan) level 3 (1,5 $\mathrm{cm})$, faktor B (berat irisan karet padatan) level 2 (5 gram), faktor $\mathrm{C}$ (suhu mesin press) level 1 $\left(180^{\circ} \mathrm{C}\right)$ dan faktor $\mathrm{D}$ (waktu pressing/ pencetakan) level 2 (6 menit).

\section{Perhitungan Analysis of Variance (ANOVA) Nilai Rata-Rata}

Dalam perhitungan ANOVA, dilakukan analisis varian terhadap respon nilai rata-rata tiap faktor dan level faktor menggunakan tingkat kepercayaan $95 \%$ yang artinya bahwa peneliti memiliki keputusan untuk menolak atau menerima hipotesis dengan probabilitas kesalahan sebesar 5\%. Hasil perhitungan ANOVA nilai rata-rata adalah sebagai berikut:

Tabel 8 Analysis of Variance (ANOVA) Nilai Rata-Rata

\begin{tabular}{|c|c|c|c|c|c|c|c|}
\hline Sumber Variansi & SS & DOF & MS & F-Ratio & SS & Rho\% & F Tabel \\
\hline A & 0,0117 & 2 & 0,0058 & 87,68 & 0,0115 & $8,09 \%$ & 3,55 \\
\hline B & 0,0097 & 2 & 0,0049 & 73,01 & 0,0095 & $6,72 \%$ & 3,55 \\
\hline C & 0,0046 & 2 & 0,0023 & 34,30 & 0,0044 & $3,08 \%$ & 3,55 \\
\hline D & 0,0092 & 2 & 0,0046 & 68,67 & 0,0090 & $6,31 \%$ & 3,55 \\
\hline Error & 0,0012 & 18 & 0,0001 & - & 0,0364 & $25,6 \%$ & - \\
\hline Mean & 0,1056 & 2 & - & - & - & - & - \\
\hline Total & 0,1420 & 26 & - & - & 0,2420 & $49,8 \%$ & - \\
\hline
\end{tabular}

Sumber: Pengolahan Data 
Pada tabel 8 juga diketahui bahwa dengan tingkat kesalahan $(\alpha) 95 \%$, nilai $\mathrm{DOF}_{\text {Faktor }}=2$ dan $\mathrm{DOF}_{\text {Error }}=18$, diperoleh nilai $\mathrm{F}-$ Tabel $\mathrm{F}_{0,05}$; $(2,18)=3,55$. Sehingga dapat diketahui bahwa faktor A, B, C dan D memiliki nilai F-Hitung > F-Tabel yang artinya faktor tersebut memberikan pengaruh yang siginifikan terhadap nilai rata-rata kualitas rubber seal tipe O-Ring. Faktor $\mathrm{C}$ yang memiliki nilai $\mathrm{F}-$ Hitung terkecil akan dipooling-up pada tahap selanjutnya untuk diuji signifikansinya terhadap kualitas rubber seal tipe $\mathrm{O}-$ Ring.

\section{Strategi Pooling Up Nilai Rata-Rata}

Strategi Pooling $U p$ adalah strategi yang dilakukan untuk menguji signifikansi faktor terhadap error pada tingkat kepercayaan $(\alpha)$ yang dilakukan dengan memaksimasi nilai varian faktor pada tabel ANOVA. Strategi ini bertujuan untuk menghindari kesalahan (error) berlebih dalam penelitian dengan mengamati faktor yang tidak signifikan, yaitu faktor yang memiliki nilai $F$-ratio $<$ F-Tabel dan faktor yang memiliki nilai $F$-ratio terkecil. Pada tabel 4.10 Analysis of Variance (ANOVA) nilai rata-rata, diketahui bahwa $F$-ratio semua faktor $>$ F-Tabel $\left(\mathrm{F}_{0,05}(2 ; 18)=3,55\right)$ yang menunjukkan bahwa faktor tersebut berpengaruh signifikan terhadap kualitas O-Ring. Namun, dari keempat faktor yang dianalisis, faktor $\mathrm{C}$ bernilai F-Ratio terkecil yaitu 34,30 sehingga faktor ini harus dipooling up dengan melakukan perhitungan nilai SS, derajat kebebasan (DOF) dan nilai MS yang baru berdasarkan nilai error yang dihitung. Sedangkan untuk faktor A, B dan D yang merupakan faktor Non-Pooled (faktor yang tidak dipooling) akan dilakukan perhitungan

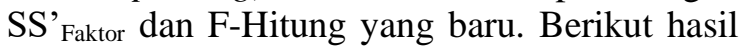
perhitungan pooling up faktor C:

Tabel 9 Analysis of Variance (ANOVA) Nilai Rata-Rata Pooling Up

\begin{tabular}{|c|c|c|c|c|c|c|}
\hline $\begin{array}{c}\text { Sumber } \\
\text { Variansi }\end{array}$ & SS & MS & F-Ratio & SS & Rho\% & F-Tabel \\
\hline A & 0,0117 & 0,0058 & 20,25 & 0,0123 & $8,64 \%$ & 3,49 \\
\hline B & 0,0097 & 0,0049 & 16,86 & 0,0103 & $7,26 \%$ & 3,49 \\
\hline C & \multicolumn{7}{|c|}{ Pooling Up } & $3,24 \%$ & 3,49 \\
\hline D & 0,0092 & 0,0046 & 15,86 & 0,0097 & $6,86 \%$ & 3,49 \\
\hline Error & 0,0012 & 0,0003 & - & 0,1097 & - & - \\
\hline Total & 0,1420 & - & - & - & - & - \\
\hline
\end{tabular}

Sumber: Pengolahan Data

Pada tabel 9 tersebut dapat diketahui bahwa faktor $\mathrm{C}$ telah dipooling up, sedangkan faktor A, B, dan D terlah dilakukan perhitungan SS' ${ }_{\text {Faktor }}$ dan F-Hitung yang baru. Hasil pada tabel 9 tersebut akan digunakan sebagai dasar dari pengujian hipotesis pada tahap selanjutnya.

\section{Pengujian Hipotesis}

Pengujian hipotesis yang diperoleh dari perhitungan ANOVA nilai rata-rata setelah pooling up faktor $\mathrm{C}$ adalah sebagai berikut:

a. Faktor A

$\mathrm{H}_{0}$ : Tidak ada pengaruh terhadap nilai ratarata kualitas rubber seal tipe $\mathrm{O}-$ Ring

$\mathrm{H}_{1}$ : Ada pengaruh terhadap nilai rata-rata kualitas rubber seal tipe $\mathrm{O}-$ Ring

Kesimpulan: F-Ratio $=20,25>$ F-Tabel $\left(\mathrm{F}_{0,05(2 ; 20)}\right)=3,49$.
Maka $\mathrm{H}_{0}$ ditolak dan $\mathrm{H}_{1}$ diterima yang artinya ada pengaruh faktor A terhadap nilai rata-rata kualitas rubber seal tipe $\mathrm{O}-$ Ring.

b. Faktor B

$\mathrm{H}_{0}$ : Tidak ada pengaruh terhadap nilai ratarata kualitas rubber seal tipe $\mathrm{O}-$ Ring

$\mathrm{H}_{1}$ : Ada pengaruh terhadap nilai rata-rata kualitas rubber seal tipe $\mathrm{O}-$ Ring

Kesimpulan: F-Ratio $=16,86>\mathrm{F}-$ Tabel $\left(\mathrm{F}_{0,05(2 ; 20)}\right)=3,49$.

Maka $\mathrm{H}_{0}$ ditolak dan $\mathrm{H}_{1}$ diterima yang artinya ada pengaruhh faktor $\mathrm{B}$ terhadap nilai rata-rata kualitas rubber seal tipe $\mathrm{O}-$ Ring.

c. Faktor D

$\mathrm{H}_{0}$ : Tidak ada pengaruh terhadap nilai ratarata kualitas rubber seal tipe $\mathrm{O}-$ Ring

$\mathrm{H}_{1}$ : Ada pengaruh terhadap nilai rata-rata kualitas rubber seal tipe $\mathrm{O}-$ Ring 
Kesimpulan: F-Ratio $=15,86>$ F-Tabel $\left(\mathrm{F}_{0,05(2 ; 20)}\right)=3,49$.

Maka $\mathrm{H}_{0}$ ditolak dan $\mathrm{H}_{1}$ diterima, artinya tidak ada pengaruh faktor $\mathrm{D}$ terhadap nilai rata-rata kualitas rubber seal tipe $\mathrm{O}-$ Ring.

Kemudian dilakukan perhitungan dengan rumus yang sama terhadap respon nilai rata-rata, analisis ANOVA dan strategi pooling up nilai Rasio S/N (variabilitas).

\section{Perhitungan Interval Kepercayaan}

Perhitungan interval kepercayaan merupakan tahap akhir eksperimen Taguchi. Perhitungan ini dilakukan untuk mencari estimasi nilai rata-rata dan nilai Rasio $\mathrm{S} / \mathrm{N}$ (variabilitas). Jika nilai hasil eksperimen berada dalam interval kepercayaan nilai estimasi, maka dapat disimpulkan bahwa rancangan eksperimen sudah memenuhi syarat metode Taguchi. Berikut hasil perhitungan interval kepercayaan untuk nilai rata-rata dan Rasio S/N: a. Interval kepercayaan nilai rata-rata untuk proses optimal:

$$
\begin{gathered}
\mu_{\text {estimasi }}-\mathrm{Cl}_{\text {mean }} \leq \mu_{\text {estimasi }} \\
\leq \mu_{\text {estimasi }}+\mathrm{Cl}_{\text {mean }} \\
-0,0028-0,0193 \leq \mu_{\text {estimasi }} \\
\leq-0,0028+0,0193 \\
-0,0221 \leq \mu_{\text {estimasi }} \leq 0,0165
\end{gathered}
$$

b. Interval kepercayaan nilai Rasio $\mathrm{S} / \mathrm{N}$ untuk proses optimal:

$$
\begin{gathered}
\mu_{\text {estimasi }}-\mathrm{Cl}_{\text {mean }} \leq \mu_{\text {estimasi }} \\
\leq \mu_{\text {estimasi }}+\mathrm{Cl}_{\text {mean }} \\
30,28-4,0599 \leq \mu_{\text {estimasi }} \\
\leq 30,28+4,0599 \\
26,2201 \leq \mu_{\text {estimasi }} \leq 34,3398
\end{gathered}
$$

\section{Perhitungan Eksperimen Konfirmasi}

Perhitungan eksperimen konfirmasi ini dilakukan untuk mengetahui estimasi nilai ratarata dan nilai variabilitas / signal to noise ratio (Rasio S/N) pada kondisi optimal yang kemudian dibandingkan dengan nilai hasil eksperimen Taguchi pada nilai rata-rata dan nilai variabilitas / signal to noise ratio (Rasio $\mathrm{S} / \mathrm{N})$ pada perhitungan sebelumnya. Berdasarkan hasil perhitungan respon nilai ratarata pada tabel 4.9, dapat diketahui bahwa faktor dan level faktor terpilih yang optimum terhadap nilai rata-rata kualitas rubber seal tipe $\mathrm{O}-$ Ring adalah:

- Faktor A (tebal karet padatan) level 3 (1,5 $\mathrm{cm}$ ),
- Faktor B (berat karet padatan) level 2 (5 gram),

- Faktor C (suhu mesih press) level $1\left(135^{\circ} \mathrm{C}\right)$,

- Faktor D (waktu pressing) level 2 (6 menit).

Dalam menghitung nilai eksperimen konfirmasi, diambil 10 sampel hasil eksperimen yang dilakukan berdasarkan faktor dan level faktor terpilih pada kondisi optimal tersebut pada tabel 10 sebai berikut:

Tabel 10 Data Proporsi Produk Cacat Hasil Eksperimen Konfirmasi (dalam Unit)

\begin{tabular}{|c|c|c|c|}
\hline $\begin{array}{c}\text { Eksperimen } \\
\text { hari ke- }\end{array}$ & $\begin{array}{c}\text { Produk } \\
\text { Cacat }\end{array}$ & $\begin{array}{c}\text { Proporsi } \\
\text { Produk } \\
\text { Cacat }\end{array}$ & $\begin{array}{c}\text { Presentase } \\
\text { Produk } \\
\text { Cacat }\end{array}$ \\
\hline 1 & 13 & 0,1625 & $16,25 \%$ \\
\hline 2 & 5 & 0,0625 & $6,25 \%$ \\
\hline 3 & 11 & 0,1375 & $13,75 \%$ \\
\hline 4 & 18 & 0,2250 & $22,50 \%$ \\
\hline 5 & 11 & 0,1375 & $13,75 \%$ \\
\hline 6 & 6 & 0,0750 & $7,50 \%$ \\
\hline 7 & 9 & 0,1125 & $11,25 \%$ \\
\hline 8 & 8 & 0,1000 & $10,00 \%$ \\
\hline 9 & 9 & 0,1125 & $11,25 \%$ \\
\hline 10 & 4 & 0,0500 & $5,00 \%$ \\
\hline Total & $\mathbf{9 4}$ & $\mathbf{1 , 1 7 5 0}$ & $\mathbf{1 1 7 , 5 0 \%}$ \\
\hline Rata-Rata & $\mathbf{9 , 4}$ & $\mathbf{0 , 1 1 7 5}$ & $\mathbf{1 1 , 7 5 \%}$ \\
\hline
\end{tabular}

Sehingga dapat dituliskan hasil perhitungan interval kepercayaan eksperimen konfirmasi sebagai berikut:

a. Interval kepercayaan nilai rata-rata eksperimen konfirmasi untuk proses optimal:

$$
\begin{gathered}
0,1175-0,0218 \leq \mu_{\text {prediksi }} \\
\leq 0,1175+0,0218 \\
0,0957 \leq \mu_{\text {prediksi }} \leq 0,1393
\end{gathered}
$$

b. Interval kepercayaan nilai Rasio S/N eksperimen konfirmasi untuk proses optimal:

$$
\begin{array}{r}
17,8998-4,5752 \leq \mathrm{S} / \mathrm{N}_{\text {konfirmasi }} \\
\leq 17,8998+4,5752 \\
13,3246 \leq \mathrm{S} / \mathrm{N}_{\text {konfirmasi }} \leq 22,4751
\end{array}
$$

\section{Analisis dan Pembahasan}

Dari hasil perhitungan interval kepercayaan nilai rata-rata dan nilai variabilitas / Rasio S/N pada perhitungan Taguchi serta nilai hasil Perhitungan Interval Kepercayaan Eksperimen Konfirmasi, didapatkan interval kepercayaan dengan tingkat kepercayaan $(\alpha)$ 95\% seperti pada tabel berikut: 
Tabel 11 Perbandingan Interval Kepercayaan Hasil Eksperimen

\begin{tabular}{|c|c|c|c|}
\hline \multicolumn{2}{|c|}{ Respon Kualitas } & Estimasi & Optimum \\
\hline $\begin{array}{c}\text { Eksperimen } \\
\text { Taguchi } \\
\text { Awal }\end{array}$ & Rata-Rata & $-0,0028$ & $\begin{array}{c}-0,0028 \pm \\
0,0193\end{array}$ \\
\cline { 2 - 4 } & Variabilitas & 30,28 & $\begin{array}{c}30,28 \pm \\
4,0599\end{array}$ \\
\hline $\begin{array}{c}\text { Eksperimen } \\
\text { Konfirmasi } \\
\text { (Taguchi } \\
\text { Hasil) }\end{array}$ & Rata-Rata & 0,1175 & $\begin{array}{c}0,1175 \pm \\
0,0218\end{array}$ \\
\cline { 2 - 4 } & Variabilitas & 17,8998 & $\begin{array}{c}17,8998 \pm \\
4,5752\end{array}$ \\
\hline
\end{tabular}

Sumber: Hasil Pengolahan Data

Pada tabel 11 diketahui bahwa estimasi nilai variabilitas pada eksperimen Taguchi bernilai sebesar 30,28 yang artinya kualitas rubber seal tipe O-Ring memiliki varians nilai yang terlalu besar. Sedangkan estimasi nilai variabilitas pada eksperimen konfirmasi bernilai lebih kecil yaitu 17,8998 yang berarti bahwa kualitas rubber seal tipe O-Ring lebih seragam dengan menggunakan kombinasi faktor dan level faktor optimal hasil eksperimen Taguchi. Pada tabel tersebut juga dapat diketahui bahwa interval kepercayaan eksperimen konfirmasi berada dalam interval kepercayaan hasil eksperimen Taguchi sehingga kombinasi faktor dan level faktor desain eksperimen Taguchi dinyatakan valid dan dapat diterima. Maka dapat disimpulkan bahwa penelitian ini dapat diimplementasikan untuk meningkatkan kualitas rubber seal tipe O-Ring di UMKM Rubber Seal RM Products Genuine Parts.

\section{KESIMPULAN DAN SARAN}

\section{Kesimpulan}

Kesimpulan yang dapat diambil dari penelitian ini adalah:

1. Metode Taguchi dalam penelitian ini merupakan metode yang menggunakan eksperimen berdasarkan data proses produksi sesuai kondisi di perusahaan yang dilakukan untuk mendapatkan desain kombinasi faktor dan level faktor yang optimal sebagai upaya pengendalian kualitas untuk mengurangi jumlah kecacatan produk rubber seal tipe $\mathrm{O}$ Ring. Kombinasi faktor dan level faktor optimal tersebut adalah faktor A (tebal irisan karet padatan) pada level $3(1,5 \mathrm{~cm})$, faktor B (berat irisan karet padatan) pada level 2 (5 gram), faktor C (suhu mesih press) pada level $1\left(135^{\circ} \mathrm{C}\right)$ dan faktor D (waktu pressing / pencetakan) pada level 2 (6 menit).
2. Kombinasi faktor dan level faktor optimal dari hasil penelitian ini memberikan memberikan perbaikan nilai variabilitas eksperimen Taguchi yaitu sebesar 30,28 menjadi 17,8998 pada eksperimen konfirmasi yang berarti bahwa data kualitas rubber seal tipe O-Ring lebih seragam dengan menggunakan kombinasi faktor dan level faktor optimal hasil eksperimen Taguchi serta memberikan penurunan nilai rata-rata persentase produk cacat dari $26,1 \%$ menjadi $11,75 \%$. Nilai tersebut masih melebihi batas standar perusahaan yaitu 5\% karena faktor yang dianalisis hanya faktor bahan baku (berat dan tebal karet padatan) serta faktor mesin press manual.

3. Interpretasi hasil perbandingan interval kepercayaan eksperimen konfirmasi bernilai $-0,0028 \pm 0,0193$ untuk nilai rata-rata dan bernilai 30,28 $\pm 4,0599$ untuk nilai variabilitas. Sedangkan interval kepercayaan eksperimen Taguchi untuk nilai rata-rata bernilai $0,1175 \pm 0,0218$ dan untuk nilai variabilitas bernilai $17,8998 \pm 4,5752$. Interval kepercayaan eksperimen konfirmasi tersebut berada dalam interval kepercayaan hasil eksperimen Taguchi sehingga kombinasi faktor dan level faktor desain eksperimen Taguchi dinyatakan valid dan dapat diterima karena telah memenuhi syarat metode Taguchi.

\section{Saran}

Saran yang diberikan dalam penelitian ini adalah sebaiknya pihak UMKM mempertimbangkan susunan faktor dan level faktor optimal yang disarankan pada eksperimen ini agar dapat memperbaiki kualitas rubber seal tipe O-Ring.

\section{DAFTAR PUSTAKA}

Anggun, Destantri. 2018. Analisis Perbaikan Kualitas Pada Batik Tulis Malang Dengan Menggunakan Metode Taguchi. Sarjana Thesis. Universitas Brawijaya.

Bagchi. 2013. Taguchi Methods Explained Practical Steps to Robust Degin. New Delhi: Published by Prentice - Hall of India Private Limited, M-97, Connaught Circus, and Printed by Bhuvnesh Seth at Rajkamal Electric Press, B-35/9, G.T. Karnal Road Industrial Area, Delhi110033 
Belavendram, N. 1995. Quality by Design: Taguchi Techniques for Industrial Experimentation. London: Prentice Hall.

Ermawati \& Hartati. 2014. Aplikasi Metode Taguchi dalam Pengendalian Kualitas Produksi. Jurnal Teknosains, Volume 8 Nomor 2, hlm. 185-194.

Kementrian Pertanian. 2019. Produksi Karet Alam per Negara Produsen Utama Tahun 2019. Jakarta: Databoks Katadata.

Liu, dkk. 2019. Optimization of Parameters in Laser Powder Deposition AlSilOMg Alloy Using Taguchi Method. Journal of Optics and Laser Technology, 111, 470-480.

Muharom dan Siswadi. 2015. Desain Eksperimen Taguchi untuk
Meningkatkan Kualitas Batu Bata Berbahan Baku Tanah Liat. Jemis Vol. 3 No. 1 Tahun 2015.

Nekere dkk. 2012. Optimization of Aluminium Blank Sand Casting Process By Using Taguchi's Robust Design Method. International Journal for Quality research Vol.6 No.1.

Rubber Association of Indonesia. 2019. Indonesia Perlu Diversifikasi Produk Olahan Karet. Jakarta: Katalog Gapkindo.

Sugiyono. 2012. Metode Penelitian Kuantitatif, Kualitatif dan $R \& D$. Bandung: Alfabeta. 